NOTES ON NATURAL HISTORY

\title{
Solanum villosum Mill. (Solanaceae): New Addition to the Flora of Rajasthan, India
}

\section{Anoop Kumar, Yogita Solanki, Amit Kotiya, Praveen Mohil}

Department of Botany, University of Rajasthan, Jaipur, Rajasthan, India-302004

\section{Introduction:}

Till date, various unique flora has been explored from the state of Rajasthan mainly for arid and semi-arid habitats (Bhandari, 1963, 1978; Puri et al., 1964; Sharma \& Tiagi, 1979; Singh, 1983; Shetty \& Pandey, 1983; Shetty \& Singh, 1991; Sharma et al., 2005; Singh \& Singh, 2006; Singh \& Srivastava, 2007; Kotia, 2008; Kotia et al., 2008). Recently, Kotia (2014), Yadav \& Meena (2016); Tiwari et al. (2016) and Dhakad et al. (2019) have further added to the knowledge on the floral composition of the state. Solanaceae, the nightshade family is distributed in tropical and subtropical regions with around 100 genera and 2500 species widely distributed throughout the world. With reference to India around 29 genera and 108 species have been recorded (Kalidas \& Panda, 2019). The genus Solanum has 49 species distributed all over the country of which only 10 species have been reported from Rajasthan.

\section{Ourobservation:}

During the floral exploration of Jaipur in Rajasthan, we collected plant specimens from the edges of agriculture fields, irrigated areas like parks, gardens, nurseries, and shady places. After detailed scrutiny of the regional flora, related research papers and attentive examination of the specimen, it has been concluded that Solanum villosum Mill. is an addition to flora of Rajasthan. Notably, S.villosum Mill. has been reported by Kumar et. al. (2013); Murugan et al. (2017) and Taram et al. (2019) from Bareilly (U.P.), Eastern Ghats and Arunachal Pradesh (India), respectively. For easy identification, key to species, updated nomenclature, detailed morphological description, phenological data, field photographs and illustrations have been provided in detail.

\section{Taxonomic description:}

Solanum villosum Mill. Dict. ed. 8. No. 2. 1768; Abedin, et al., 1991 (Pak. J. Bot. 23:271); Kumar, et al., 2013 (Indian Forest. 139:1053), Solanum miniatum Bernh. Ex Willd., 1809 (Enum. Pl. 1: 236), Solanum nigrum var. humile (Bernh. Ox Willd.) Wu \& Haung, 1978 (Acta Phytotax. Sin. 16:72).

Specimens examined: Corresponding author (AK) (RUBL- 211728, Date: 22/12/2019), collected from Jaipur

\author{
Study Area:Jaipur, Rajasthan, India \\ Coordinated: - $26^{\circ} 48^{\prime} 15^{\prime \prime}$ to $27^{\circ}$ oo' $15^{\prime \prime} \mathrm{N}$; $75^{\circ} 41^{\prime} 15^{\prime \prime}$ to $75^{\circ}$ \\ $53^{\prime} 45^{\prime \prime} \mathrm{E}$
}

Key words: Semi-arid, Nightshade family

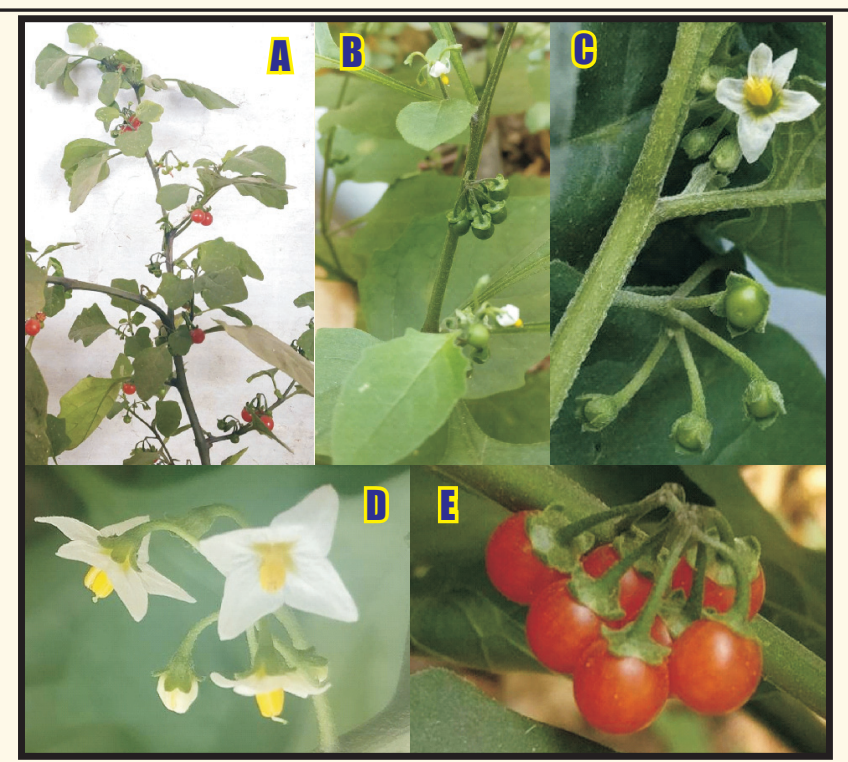

Plate-1: Solanum villosum Mill. (A) Full grown plant (B) A twig (C)

Flower \& immature fruits (D) Inflorescence (E) Mature fruits

District, Rajasthan, India.

Unarmed, much-branched, annual or short-lived perennial herb upto $40-100 \mathrm{~cm}$ height, slightly greyish, villous, pubescent with simple (uniseriate multicellular) and glandular hairs. Stem- greenish, terret with dentate ridges on lateral sides. Leaves- simple, alternate, ovate or ovate-lanceolate 5.5-10.5 ×3.5-6.5 cm long, apex acute, base decurrent, leaves margin entire to lobed (4-6 lobed), slightly pubescent, pinnatif id venation, petiole $1-2 \mathrm{~cm}$ long. Inflorescence- extra axillary, sub-umbellate raceme of 4-8 white-flowered, peduncle ca. $1 \mathrm{~cm}$ long, erect, pedicels 5-10 $\mathrm{mm}$ long, glabrous, flowers regular, pentamerous, complete, actinomorphic. Calyx- lobes acute, ca. $2.5 \mathrm{~mm}$ long, green, finally recurved away from mature berries, persistent, macrescent. Corolla- 5- lobed, ovate, 3-4 mm long white with translucent to yellow basal star, apex acute, reflexed. Stamens- yellow, 5 in number, filaments ca. 0.5 $\mathrm{mm}$ long, Anthers- connivent (convergent apically without fusion), oblong, dithecous, ca. $2 \mathrm{~mm}$ long, basifixed, porocidal dehiscence. Style- about $3.5 \mathrm{~mm}$ long, densely villous at the base to middle, glabrous, exerted. Stigma- 
capitate, green. Ovary- globose, $<1.5 \mathrm{~mm}$ long. Berriessubglobular, orange or orange-red, $5-7 \mathrm{~mm}$ in diameter, Seeds-discoid, paleyellow, compressed (Plate-1, Fig.-1).

Flowering \& Fruiting: October to February. Note- The plant can grow on a wide range of soils but prefers organic matter rich soil. The plant shows flowering even when it has mature fruit on the lower branches and immature fruit on the middle branches.

\section{Artificial Key}

1a Plantarmed

2a Flowers pale, purple orviolet purple

za Berries more than $1 \mathrm{~cm}$ in diameter

4a Prickles straight

5a Fruits bright red when ripe.........

5b Fruits yellow when ripe ............

4b Prickles recurved

S.sisymbriifolium

S.virginianum

S.incanum

3b Berries less than $1 \mathrm{~cm}$ in diameter

6a Erectshrubor under shrub

7a Petioleand pedicle prickly

8a Calyx lobesacute ............ S.anguivi

8b Calyx lobes acuminate-cordate...... S.trilobatum

7b Petioleand pedicel not prickly ....... S.albicaule

$6 \mathrm{~b}$ Trailing or subscandent under-shrubs

2b Flowers white

9a Hairs present on berries ............ S.ferox

9b Hairs absent on berries ................. S.torvum

ib Plant unarmed 1oa Leaves hastate..... S.triquetrum

1ob Leaves ovate to oblong

11a Peduncle longer than pedicel, Fruit black when ripe.....

S.nigrum

11b Peduncle shorter or equal to the pedicel, Fruit orange when ripe

S.villosum

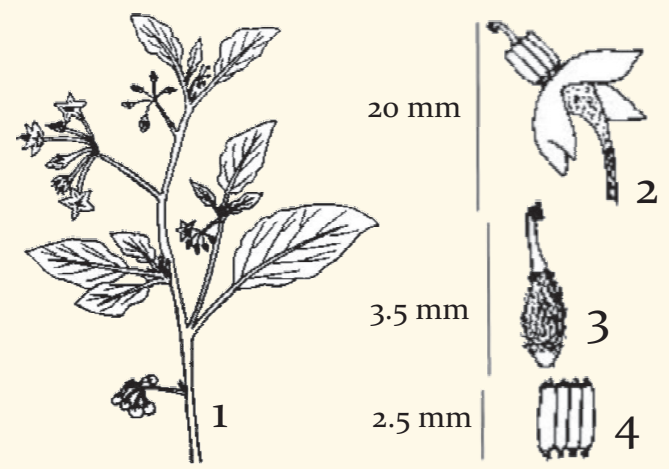

Figure-1: Solanum villosum Mill. 1. Twig 2. Single Flower 3. Gynoecium 4. Stamens

Acknowledgements:

The authors are grateful to the Head, Department of Botany, University of Rajasthan, Jaipur, and Head of Forest, Rajasthan State Forest Department, Jaipur for their unfailing encouragement and support.

\section{References:}

Bhandari, M.M. (1963): Notes on Indian Desert plants-I. New records for North Western Indian Desert. Rajasthan Acad. Sci Proc., 10 (1):40-50.
Bhandari, M.M. (1978): Flora of the Indian Desert. Pub. by: Scientific Publisher, Jodhpur (India). 435 P.

Dhakad, M., Kotiya, A., Chandrawal, K., Khandal, D. \& Meena, S.L. (2019): Elatostema (Urticaceae): a new generic record to the flora of Rajasthan, India. Indian J. Forest., 42(1):49-51.

Kalidas, C. \& Panda, P.C. (2019): The Genus Solanum L. (Solanaceae) in Eastern Ghats of India. Pub. by: Regional Plant Resource Center, Bhubaneswar, Odisha, India. 76 P.

Kotia, A. (2008): Threatened plants and their habitats in Indian Thar Desert. Special Habitats and Threatened Plants of India. ENVIS Bull. 11(1):93-99.

Kotia, A. (2014): Biodiversity losses of Indian Thar Desert (Rajasthan) special reference to endemic and threatened plants species, pp9-18. In: Biodiversity in India: Assessment, Scope and Conservation. Pub. by: Lambert Academic Publishing, Germany. .

Kotia, A., Tiwari, U., \& Rawat, G.S. (2008): Semiarid region of India: vegetation characteristics and Threatened Plants. Special Habitats and Threatened Plants of India. ENVIS Bull., 11(1):109-116.

Kumar, R., Khare, A.K., Singh, H. \& Mishra, U.S. (2013): Addition to the flora of upper Gangetic plain: status of Solanum villosum Mill. A new record from Bareilly, Utter Pradesh. Indian Forest., 139(11):1052-1053.

Murugan, P., Kalidass, C. \& Panda, P.C. (2017): Solanum villosum Mill. (Solanaceae): a new plant records for Eastern Ghats of India. Indian J. Forest., 40(1):73-75.

Puri, G.S., Jain, S.K., Mukerjee, S.K., Sarup, S. \& Kotwal, N.N. (1964): Flora of Rajasthan. Rec. Bot. Sur. India, 19:1-159.

Sharma, S. \& Tiagi, B. (1979): Flora of North-East Rajasthan. Pub. by: Kalyani Publishers, New Delhi. 540 P.

Sharma, S.K., Katewa, S.S. \& Bhatnagar, C. (2005): New records of the plants from Rajasthan. Zoos'Print, 20(9):1984-1985.

Shetty, B.V. \& Pandey, R.P. (1983): Flora of Tonk District. Pub. by: Botanical Survey of India, Howrah, Kolkata. 253 P.

Shetty, B.V. \& Singh, V. (1991): Flora of Rajasthan (Vol.-II). Pub. by: Botanical Survey of India, Howrah, Kolkata. 408 P.

Singh, V. (1983): Flora of Banswara District. Pub. by: Botanical Survey of India, Howrah, Kolkata. 312 P.

Singh, V. \& Singh M. (2006): Biodiversity of Desert National Park Rajasthan. Pub. by: Botanical Survey of India, Howrah, Kolkata. 344 P.

Singh, V. \& Srivastava, A.K. (2007): Biodiversity of Ranthumbhore Tiger Reserve Rajasthan. Pub. by: Scientif ic Publisher, Jodhpur, India.

Taram, M., Ghosh, C., Das, A.P. \& Tag, H. (2019): Solanum villosum Mill. (Solanaceae)- a new record for the flora of Arunachal Pradesh, India with notes on its distribution in Eastern India. Pleione. 13(2):411-415.

Tiwari, U.L., Ravikumar, K., Balachandran N. \& Sharma, S.K. (2016): Some new records of plants from the state of Rajasthan, India.J. Threatened Taxa. 8(3):8632-8637.

Yadav, B.L. \& Meena, K.L. (2016): Solanum sisymbriifolium Lam.: A new record for Rajasthan, India. J. Econ. Taxon. Bot., 32(3):749-753. 